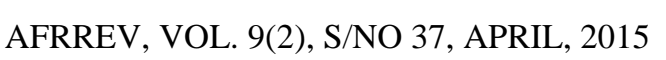 \\ African Research Review
}

An International Multidisciplinary Journal, Ethiopia

Vol. 9(2), Serial No. 37, April, 2015:189-196

ISSN 1994-9057 (Print) ISSN 2070-0083 (Online)

DOI: http://dx.doi.org/10.4314/afrrev.v9i2.14

\section{Effective Management of Human Resources for Business and Church Growth}

\author{
Jaja, Seth Accra \\ Department of Management, Faculty of Management Sciences \\ Rivers State University of Science and Technology \\ Nkpolu, Oroworukwu, Port Harcourt \\ $\&$ \\ Arugu, Love O. \\ Department of Political Science and Strategic Studies \\ Federal University, Otuoke \\ Bayelsa State, Nigeria
}

\begin{abstract}
Manpower is one of the many resources of an organization. Its relevance cannot be over emphasized as it combines other resources such as capital, materials, and machines, together to achieve organizational goal. Therefore effective management of human resources is pertinent for business and church growth. In managing human resources, the personality of the individual plays a key role. Personality is an enduring characteristic that shape individual contribution to the organization's growth. It could be normal or abnormal and it develops from hereditary, socialization, cultural and situational phenomena. Managers must be conscious of the individual personality and provide inner compass that guides individual breakthrough in the dynamic business and church environment. Members should be given the right to express themselves and the conflicts arising from the differences in opinion resolved within a limited time constraint, as this will make the business and the church organization more stable. While one person can begin a business or a church, the
\end{abstract}

Copyright (C) IAARR, 2015: www.afrrevjo.net

Indexed African Journals Online: www.ajol.info 
management of the business and church organizational activities should be left in the care of many who are willing to accept and discharge such obligations and responsibilities desire to maintain it, notwithstanding that such individuals are not the person(s) who started the business or the church.

Key words: Effective management, human resources, business, church, growth

\section{Introduction}

Business and churches are a form of formal organization whose objectives include among others, tangible and intangible benefits, survival, maintenance of good public image and the target market including growth (Jaja and Okwandu, 2007). In this lecture-discussion, the emphasis is on growth objectives. These include expansion which has to do with opening up branches or units outside the headquarters of the business or church with the same product line. The other aspect of growth is diversification which has to do with adding new product lines to the original product being offered by the business or the church. Another growth element is in the size perspective. This can be identified in the development of structure, infrastructure and increase in the number of employees.

The notion of interrelatedness in socio-organizational life of business and the church suggest that they are institutions made up of goal-oriented arrangement, psycho-social system, technological systems, and integrated activity structure (Jaja and Zeb-Obipi, 1999). Generally, businesses as well as churches are known to create wealth through established values which are exchanged at a risk for the benefit of the risk bearers. In addition to this, the church as a strategic organization has other specific objectives such as evangelism mission, intercession, preaching, teaching, spiritual warfare, praise, worship and welfare. The question before us is how do we adopt effective human resources management practices to build business and church growth?

It is pertinent to point out here that, consequent upon a myriad of changes, which have beclouded the operations of businesses and churches in recent time, a need for entrenching social relational domain (SRD) skills in human resources management practice has arisen. In doing this, entrepreneurial managers and churches must infuse their responsibilities in the human resources management process with the changing societal needs. The managerial elements in process include manpower planning, recruitment, selection, training, salary and wage administration, performance appraisal, grievance management, and retirement management. The changing needs are in the area of: (1) a new way of ordering the idea of work; (2) vision, ethics and responsiveness to cultural diversity; (3) movement from human to social action; and (4) coupling the visible and invisible spirit of management. 
Drawing from the challenges in real life business and church management situations, the specific issues to be discussed will be: (1) development of human potential and skill requirements; (2) individual personality construct; and (3) SRD of HRM practice effectiveness skills HRM-PES.

\section{Human Potential Development and Skill Requirement}

At birth, a normal human being comes with an enormously wide range of behavioural characteristics and potentialities which are contained in his or her physical, emotive and cognitive endowments. As the individual grows, these endowments are conditioned and through a process of learning, the human being is infused with skills, knowledge, and abilities, which are of both general and specialized nature. These capabilities then convert him or her into human capital. This implies equipping the individual with productive potentials. When these potentials are appropriately deployed and effectively utilized at work through an enduring human resources management culture, value is produced. This in turn results in organizational goal attainment.

It is pertinent to mention that leader-managers at different levels need different type of skills. Lower-level managers need technical skills more than higherlevel managers, who rely more on conceptual skills Leader-manager at all levels however need human relations skill. Technical skill has to do with the ability to use procedures, techniques, and knowledge of a specialized field. Human relations skills involve the ability to work with, understand and motivate others. Conceptual skill relates to ability to coordinate and integrate all interests and activities in business and the church in a unique way. For church management, the leader-manager is describable in the structure of minister-church workers' interface.

\section{Individual Personality Construct and HRM-PES}

In African work places, followers want comfort, stability, and solutions from their leader-managers (Heifetz and Laurie, 2001; Collins, 2001; Jaja, 2003; Cadbury, 1987). The solution to the resulting adjustment and adaptive challenges to the situation resides in the individual's personality construct. The leader-manager must therefore learn to take responsibility for the development of HRM-PES in themselves and their subordinates for business and church growth (Gazzaniga and Heatherton, 2010; Roberts et al, 2005; Heifetz and Linsky, 2002). This is because, without a realization of the nature of an individual's personality construct, it is not likely for the individual's effective use of his valued HRM-PES (Hamilton and Jaja, 2008, Roberts et al, 2005). To this end, we lean on Bennis and Thomas (2002) argument that, eveiy individual is tested by life through his acquired HRM-PES, but only a few extract strength and wisdom from these skills. 
Goleman (2000) and Jaja (1996) observed that effective use of HRM-PES can be learned. A Seventeenth Century Philosopher, Booker T. Washington has considered this idea of learning to be so important in the life-world of business and church, that he described learning to be a social glue which can bind an individual's personality and his perceived HRM-PES. In another instance, Pliny the Elder, an Eleventh Century Philosopher has underscored the inevitability of learning in the development and application of HRM-PES, when he assertively admonished people saying: man is the only one that knows nothing and learns nothing good without being taught. As Charles Lamb, a Nineteenth Century Psychologist opined, you may derive thought from others, but your way of thinking and moulds in which your thoughts are cast must be your own.

Based on the insight we have received from critical review of the currently leading literature on the subject matter (including Allport, 1935; Vernon, 1950; Heatherton and Weinberger, 1994; Horgan et al, 2007; McAdams, 2009) we are inclined to believe that personality is the dynamic organization within the individual of those psycho-physical structures which determine his unique adaptation and adjustment to his environment. This implies that personality is the sum total of the ways in which an individual reacts and interacts with others within his environment subject to the limitations of acquired HRM-PES. In other words, it is an enduring characteristic that shape an individual's contribution to business and church growth.

The personality construct for HRM-PES can be analysed on the basis of nature-nurture debate, interactionist, psycho-analytic and psycho-metric perspectives. The construct is also known to have been drawn from or domiciled in hereditary, socialization, cultural and situational phenomena. A host of scholars have, shown that individual personality can be normal or abnormal (Jaja, 2003; Ahaiuzu, 1999). The abnormal personality has to do with psychotic and neurotic behaviours. The psychotics are those who are: (1) in the habit of destroying valuable things - manic depression; (2) doing different things at the same time and therefore have split personality - schizophrenia; and (3) suffering from physical brain disorder and daydreaming- paranoia. The neurotics are those suffering from: (1) excessive fatigue and bodily discomfort without reasonable cause- neurasthenia; (2) dual personality or being and Hysterical-disassociation and (3) phobia or excessive worries such as fear of enclosure, darkness or height - anxiety.

\section{Social Relational}

\section{Domain of HRM-PES}

Science has proved that it is social relations rather than the raw brainpower alone that underpins the development and application of many HRM-PES in business and the church (Ahiauzu, 1999). This implies that, social relations are the primary 
domain of human energy, interest, aspiration, and drive that activate individual innermost values and purpose in business and the church (Ahiauzu, 1999). To this end, SRD ignites trusting relationships, consolidates integrity, clarifies decision, and provides an inner compass that guide individuals' breakthrough in the dynamic business and church environment.

As we explained elsewhere (Hamilton and Jaja, 2008; Jaja, Hamilton and Obiora, 2014), SRDs are not innate talents, but learned abilities, and as such through certain spiritual life-world practices and experiences, they produce the effect of continuous improvement in business and the church. The skills include: (1) perceived focal person action; (2) human perception and impression management consciousness; (3) quality industrial counselling, motivational language and selfefficacy perception; (4) respectful handling of subordinate, humour and story-telling; and (5) trust, integrity, and emotional hardiness.

\section{Practical Implications}

The challenge facing most business and church organizations globally remains developing an effective strategy for achieving growth through the application of HRM-PES. In HRM-PES discourse, social interaction is a fundamental variable, given that the more entrepreneurial businesses and churches encourage social lubrication, the more committed their members would be in contributing to the much expected growth. To this end, it is pivotal that leader-managers in businesses and the churches must create a climate conducive for workplace coupling.

Workplace coupling climate (WCC) has to do with the interplay of social relational practices between superiors and subordinates in businesses and the church. It has to do with superior's socially conceived actions toward their subordinates and their responses to this. The socially ingrained actions can be displayed through programmes of organizational support to subordinates, provision of opportunities for creativity and innovation. These organisational socially constructed actions tend to shape the contribution of individuals toward business and church growth.

The relationship being referred to, include the exchange of material and nonmaterial products that extend beyond what is specified in the formal job description or the church constitution. To energize and sustain this trend, leadermanagers must motivate organization- members to engage in extra-role discretionary activities that will benefit and help in achieving business and church growth. This discretionary activity is termed Organizational Citizenship Behaviour (OCB).

OCB has been used to represent and measure individual organizationmember's discretionary attitude in terms of valuing and supporting their colleague roles. It is well known that within the church organization, greater levels of OCB encourage members to improve their participation in both defined and extra role 
behaviours as they feel obligated to assist the business and church organization in reaching their objectives (Organ et al, 2006; Podskakoff et al; 2000). Five distinct measures of OCB can be used in measuring organization members' contributions to business and church growth. These are: (1) altruism - helping behaviours directed at specific individuals; (2) courtesy - informing others to prevent the occurrence of conflicts; (3) sportsmanship - tolerating the inevitable inconveniences in business and the church without complaining; (4) conscientiousness - going beyond minimally required levels of attendance; and (5) civic virtue - participating in and being concerned about the health of business and the church. Three implications can be drawn from the foregoing discussions. The first is that OCB is a discretionary behaviour. Secondly, it is not rewarded by any schedule or policy of remuneration. Thirdly, it promotes the effective functioning of business and the church.

The individual can learn to recognize the HRM-PES he picks up subconsciously which complement his personality construct. This is because, the individual is like a radio that can receive many frequencies, but what is received depends on what he pays attention to. There is evidence that in contemporary business and church economies, many frontiers are opening. Similarly, the ability to be aware of and affected by previously invisible and unseen competencies in business and church management are also increasing. It is our belief therefore, that an effective and efficient leader-manager in a business or the church should be conscious and sensitive to these developments. The implication here is that leader-managers in businesses and the churches are expected to develop wisdom, release positivism, and rise above negativity in the discharge of their responsibilities.

\section{Conclusion and Recommendations}

The human resources management practices normally bear fundamental influence in shaping the nature of orientation, aspiration and the general world-view of the human being in business and the church. The relevant culturally induced human resources management policies and practices therefore normally influence the distribution of skills in the structure of business and the church. Human resources management is therefore living in the middle of the relationships that make up the sustenance of business and church growth. To create and maintain sustainable business and church growth path, it is recommended that:

1. Members should be given the right to express themselves and the conflicts arising from the differences in opinion resolved within a limited time constraint, as this will make the business and the church organization more stable.

2. While one person can begin an organization. The management of the business and church organizational activities should be left in the care of many who 
are willing to accept and discharge such obligations and responsibilities desire to maintain it, notwithstanding that such individuals are not the person(s) who started the business or the church.

3. A weak leader-manager can follow a strong one, but not another weak one, and maintain his authority in the business or the church.

4. A leader-manager seeking to change an established culture of the business or church organization should not do so in a blitz and should at least retain a shadow of the ancient customs.

5. If for any reason or challenges the growth objectives are not yet achieved, the leader-manager in the business or the church should never surrender.

Ahiauzu, A. I. (1999). The African industrial man. Port Harcourt: CIMRAT.

Allport, G.W. (1935). Attitudes. In Marchison G. M (ed.) Handbook of Social Psychology, Worcester: Mass Clark University Press: 45- 55

Bennis, W. C. \& Thomas, R. J. (2002). Crucibles of leadership. Harvard Business Review. (September): 1-9.

Cadbury, A. (1987). Ethical managers make their own rules. Harvard Business Review, (September-October): 1-6

Collins, J. (2001). Level 5 Leadership: The triumph of humility and fierce resolve. Harvard Business Review, (July - August): 1-11

Gazzaniga, M. S. \& Heatherton, T. F. (2010). Psychological science. New York: W. W. Norton and Company.

Coleman, D (2000). Leadership that gets results. Harvard Business Review, (March April): 77-90.

Hamilton, D.I. \& Jaja, S.A. (2008). Strategies of administrative control: A study of business organisations in Nigeria. European Journal of Scientific Research, 19, (3): 501-509.

Heatherton, T. F. \& Weinberger, J. L. (1994). Can personality change? Washington, D C: American Psychological Association.

Heifetz, R. A. \& Laurie, D. L. (2001). The work of leadership. Harvard Business Review, (December): 5-15.

Heifetz, R. A. \& Linsky, M. (2002). A survival guide for leaders. Harvard Business Review, (June): 20-31.

Horgan, R., Johnson, J. \& Briggs, S. (2007). Handbook of personal psychology. San Diego: Academic Press.

Jaja, S. A. (1996). Learning organisation and consumer satisfaction: The Nigerian experience. Productivity, 37 (1): 73-83.

Jaja, S. A., Hamilton, D. I., \& Obiora, J. N. (2014a). Development and application of personal effectiveness skills at work, Being Paper Presented at a Workshop 
on Personal Effectiveness Skills/Office Protocol for Administrative Assistants, Organised by Niger Delta Development Commission (NDDC) in Collaboration with Atieke Amaso \& Co. in Port Harcourt from November 3 to 11 .

Jaja, S. A. (2003). Praxis of work behaviour, Lagos, Nigeria: Pinnacle Publishers.

Jaja, S. A. \& Zeb-Obipi, I. (1999). Management: Elements and theories. Port Harcourt, Nigeria: Pearl Publishers.

Jaja, S. A. \& Okwandu, G. A. (2007). Understanding business management: Insights and critical issues. Port Harcourt, Nigeria: Pearl Publishers.

McAdams, D. P. (2009). The person: An integrated introduction to personal psychology, Fort Worth: Harcourt.

Obiora, J. N. Hamilton, D. I. \& Jaja, S. A., (2014). Underpinning of workplace coupling climate for personal effectiveness skills, Being Paper Presented at a Workshop on Personal Effectiveness Skills/Office Protocol for Administrative Assistants, Organised by Niger Delta Development Commission (NDDC) in Collaboration with Atieke Amaso \& Co. in Port Harcourt from November 3 to 11 .

Organ, D. W. (1988). Organizational citizenship behaviour: The good soldier syndrome, Lexington, MA: Lexington Books.

Organ, D. W., Podsakoff, P. M. \& Mackenzie, S. B. (2006). Organizational Citizenship Behaviour. Its Nature, Antecedents and Consequences, Thousand Oaks, CA: Sage.

Podsakoff, P. M., Mackenzie, S. B., Paine, J. B., \& Bacharach, D. C. (2000). Organizational citizenship behaviours: A critical review of the theoretical and empirical literature and suggestions for future research. Journal of Management, 26, 513-563.

Roberts, L. M., Spreitzer, G., Dutton, J., Quinn, R., Heaphy, E. \& Barker Brianna (2005). How to play to your strengths. Harvard Business Review: (January): $1-7$.

Vernon, P. E. (1950). The structure of human abilities. London: Methuen. 